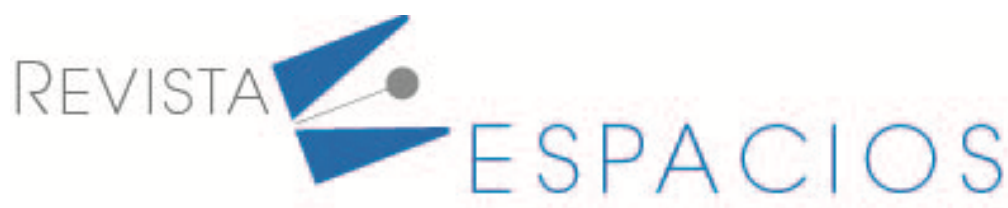

Vol. 41 (49) $2020 \cdot$ Art. 9

\title{
External funding and the development of small and medium- sized businesses in the city of Makassar (Indonesia): an explanatory quantitative study
}

\section{Financiamiento externo y desarrollo de pequeñas y medianas empresas en la ciudad de Makassar: un estudio cuantitativo explicativo}

\author{
THAHA, Salmiyah ${ }^{1}$ \\ MUSA, Chalid I. ${ }^{2}$ \\ BADO, Basril ${ }^{3}$
}

\begin{abstract}
Academics are interested in exploring small and medium business actors both from a macro perspective that examines external factors in developing small and medium business actors, as well as from a micro perspective on internal determinants that contribute to the performance for small and medium enterprises. The purpose of this study was to analyze the effect of entrepreneurial character on external funding and the development of small and medium business actors. This research is a quantitative study that explains the influence of exogenous variables on endogenous variables. Research location in the city of Makassar, South Sulawesi. The population in this study were 136 entrepreneurs who made loans to banks (State-owned enterprises) in the city of Makassar. The sampling of this study used the census sampling method (saturated sample). The data collection method uses a survey method with primary data collection in the form of a questionnaire. Data analysis techniques using structural equation modelling. The results showed that the entrepreneurial character variable had a significant effect on external funding and the development of small and medium business actors. Therefore, based on research findings, efforts to enhance the development of small and medium business actors in further research can develop further models.
\end{abstract}

key words: entrepreneurial, business, development.

\begin{abstract}
Resumen
Los académicos están interesados en explorar los actores de la pequeña y mediana empresa tanto desde una perspectiva macro que examina los factores externos en el desarrollo de los actores de la pequeña y mediana empresa, como desde una perspectiva micro sobre los determinantes internos que contribuyen al desempeño de la pequeña y mediana empresa. El propósito de este estudio fue analizar el efecto del carácter emprendedor sobre el financiamiento externo y el desarrollo de los actores de la pequeña y mediana empresa. Esta investigación es un estudio cuantitativo que explica la influencia de las variables exógenas sobre las endógenas. Lugar de investigación en la ciudad de Makassar, South Sulawesi. La población en este estudio fueron 136 empresarios que hicieron préstamos a bancos (empresas estatales) en la ciudad de Makassar. El muestreo de este estudio utilizó el método de muestreo censal (muestra saturada). El método de recopilación de datos utiliza un método de encuesta
\end{abstract}

\footnotetext{
${ }^{1}$ Department of Economic, Universitas Negeri Makassar, South Sulawesi, Indonesia. e-mail: mia.thaha@gmail.com

2 Professor, Universitas Negeri Makassar, Affiliate Professor Universitas Negeri Makassar, South Sulawesi, Indonesia. e-mail: imranmusa1962@gmail.com

${ }^{3}$ Department of Economic, Universitas Negeri Makassar, South Sulawesi, Indonesia. e-mail: basri.bado@unm.ac.id
} 
con recopilación de datos primarios en forma de cuestionario. Técnicas de análisis de datos mediante modelado de ecuaciones estructurales. Los resultados mostraron que la variable carácter emprendedor tuvo un efecto significativo sobre el financiamiento externo y el desarrollo de los actores de la pequeña y mediana empresa. Por lo tanto, sobre la base de los resultados de la investigación, los esfuerzos para mejorar el desarrollo de los actores de las pequeñas y medianas empresas en futuras investigaciones pueden desarrollar nuevos modelos.

palabras clave: emprendedor, empresarial, desarrollo.

\section{Introduction}

Each country has different policies to help the development of small and medium enterprises. Ruchkina et al. (2017) explain that the most effective strategy for small and medium business actors is to increase their business innovation in a structured manner. However, Ruchkina's statement was criticized by Sayal \& Banerjee (2017), who stated that there is no most effective and ideal model for solving various problems of small and medium business actors. This is disputed by Bannier \& Zahn (2014) that the right policy or model for developing small and medium business actors is to cluster their heterogeneous businesses to be developed based on the criteria of each small and medium business actor. Whereas Wakkee et al. (2015) and Schmitt (2018) consider that the ideal development of small and medium business actors is to identify financing and human capital factors.

Policies in developing small and medium business actors in Indonesia are different from other countries; this is inseparable from the characteristics of Indonesia as an archipelago. There are differences between one region and another, in terms of the development and performance of small and medium businesses. Based on data from the Indonesian bank in 2018 that the population of small and medium businesses in Indonesia was 8.2 million businesses. The most significant number of small and medium business operators are in West Java, East Java, Sumatra, and East Java. Bank Indonesia also released data on the competitiveness for small and medium enterprises, that South Sulawesi in general and the city of Makassar, in particular, have low competitiveness compared to some regions in Indonesia.

The low development of small and medium business actors in the city of Makassar can also be observed from the support of previous research. Yunus (2017) explained that the performance of small and medium businesses in Makassar is determined by the ability of entrepreneurs to improve entrepreneurial competence. Other researchers such as Abduh (2016) emphasize the business strategy approach that is appropriate to the characteristics of small and medium business actors in the city of Makassar. At the same time, Nadhar (2017) and Wiradirnata (2016) assess that the performance problems of small and medium business operators in the city of Makassar can be overcome through efforts to increase motivation in entrepreneurship. Alyas and Rakib (2017) argue that among the problems that were the main obstacles to the development of small and medium businesses in Makassar, namely the constraints on venture capital was the most critical problem.

Capital problems have become a classic problem that is almost experienced by all small and medium business actors throughout Indonesia. Sukoco et al. (2015) state that if the capital problem can be resolved, then low and medium business actors will quickly develop their businesses and be able to compete competitively. The better the capital of small and medium business actors, the more excellent the opportunity to increase income from business results (Riawan \& Kusnawan, 2018). Thus the capital factor can be a key factor in determining the improvement of the performance of small and medium businesses.

The government, banking financial institutions, non-banking institutions, as well as state-owned companies have long responded to the problem of capital for small and medium business actors by providing some business capital assistance to small and medium business actors. Providers of soft support such as state-owned enterprises and the government also conduct development and guidance to the small and medium-sized 
businesses they foster. Likewise, from the banking side, which has channelled people's business credit (people's business credit) to various types of small and medium business operators in South Sulawesi, as much as Rp. 5.85 trillion or 108.31 per cent of the target of 2018 people's business credit.

Wahyuniardi's findings (2012) stated that although there was an increase in the nominal amount of distribution of venture capital assistance to small and medium enterprises, the obstacles experienced by small and medium business actors included (a) socialization about venture capital assistance had not been maximized; (b) weak assistance and supervision from related parties; (c) uneven distribution of business capital assistance; (d) relatively high-interest rates; (e) requirements of prospective debtors that are difficult for entrepreneurs to fulfil; and (f) collateral for business owners.

Access to external funding sources is influenced by entrepreneurial character; the link is explained by Frid et al. (2016) that the higher the aspect of one's entrepreneurship, the greater access to funding or credit. The problem of entrepreneurial character can be observed from the behaviour of small and medium business entrepreneurs. They are afraid of banking institutions because they are afraid of not being able to repay loans (Fatimah \& Darna, 2011). The central phenomenon of the character of entrepreneurship is that many of the small and medium business actors are workers' character, behave like labourers, are challenging to develop, are not ambitious, do not want to take risks, and are not easy to accept outside influences (Retnandari, 2009). The purpose of this study was to analyze the effect of entrepreneurial character on external funding and the development of small and medium business actors.

\section{Literature Reviews}

\subsection{Entrepreneurial character}

There are various factors that are responsible for internal entrepreneurial success. Academics and researchers have different opinions about the effect of various factors on entrepreneurial success. However, it has been confirmed by the majority of researchers that the character of entrepreneurship plays a vital role in achieving entrepreneurial success (herdianti et al, 2016). The topic of personality or psychological character of entrepreneurship is significant for the study of entrepreneurship in a variety of contexts, including analysis of the determinants of job choices (entrepreneurship vs office work), predictors of entrepreneurial success, evaluation of the impact of entrepreneurial policies, and the design and assessment of various approaches to entrepreneurship (kerr, 2017).

There are inherent characteristics in entrepreneurship, such as commitment, determination and perseverance, the need for achievement, opportunity orientation, initiative and responsibility, ongoing problem solving, feedback, internal locus control, tolerance for ambiguity, risk-taking tendencies, integrity and reliability, tolerance for failure, high energy levels, creativity and innovation, vision, self-confidence and optimism, independence, and team building. An entrepreneur can look ahead by thinking through calculations looking for choices from various alternative problems and solutions (Akeem \& Adekanmbi, 2016).

There are characteristics (attributes) that are often inherent in entrepreneurship, such as commitment, determination and perseverance, the need for achievement, opportunity orientation, initiative and responsibility, continuous problem solving, feedback, internal locus control, tolerance for ambiguity, tendency to take risk, integrity and reliability, tolerance for failure, high energy levels, creativity and innovation, vision, self-confidence and optimism, independence, and team building (Fitriani \& Hermit, 2010). 


\subsection{External funding}

External funding is one of the strategic factors in running a business. Capital is a vital part of the activities and activities of a company (Sukoco et al. 2015). The stronger the capital owned, the more productive business activities (Boso, 2016). The contribution of money to a business becomes an essential foundation in business. Several types of capital are needed in business activities or activities, including financial capital and non-financial capital. Capital structure is considered as the most important parameter that influences company valuation (Bakhshani, 2017).

Increasingly competitive business competition, increasingly advanced technological innovations and the era of globalization in this century, forced business organizations to change the way they conduct their business activities. A change in business strategy is needed so that business organizations can continue to survive. Business organizations can develop and sustain the industrial revolution 4.0 if the growth of physical capital and financial capital is in line (Isaksson \& Quoreshi, 2015).

Physical capital, as one of the factors of production controlled by an entity, is seen as physical production capacity in the form of the ability to produce goods and services. Physical capital consists of current assets and fixed assets. In general, regular and permanent existing assets are needed to carry out an organization's operational activities. Likewise, with fixed assets, these assets are also significant for production activities because, without equipment, machinery, buildings, vehicles and land, there will be no production activities in the manufacturing industry. The availability of physical capital in the industry to function to carry out business continuity will be guaranteed (Sharafeddine, 2016).

\subsection{The development of small and medium businesses}

Attention about research into the development of small and medium-sized businesses is significant in neighbouring countries such as Malaysia which rely on the growth for small and medium-sized enterprises in their economy, small and medium, high-income and knowledge-based entrepreneurs so that they contribute to Malaysia's GDP. A significant contribution to exports, employment and economic growth (Moorthy et al. 2012). Research fouad (2013) explains that low management skills such as human resources, financial management, general management, production management and marketing management influence the decline in the development of small and medium enterprises in the manufacturing sector.

Small and medium businesses (small and medium business actors) have an important role to play in the development of the country. The strong small and medium business sector contributes greatly to the economy, contributes to the gross domestic product, by reducing unemployment, reducing poverty, and promoting entrepreneurial activities. The findings of Sitharam \& Hoque (2016) reveal that technological advancements will enhance the development of small and medium business actors. Crime and corruption affect the decline in the development of small and medium businesses. Competition is the only factor among the internal and external factors understudy that reveals a significant relationship with the improvement and development of small and medium business actors.

Small and medium businesses contribute to job creation because it is one of the sectors that provide industrial employment in developing countries. In general, small and medium business operators use local raw materials that do not require high-level technology to be processed into finished products, and this effectively reduces rural-urban migration. Small and medium businesses use simple technology and recycle waste from large companies as input for the production process. 


\section{Methodology}

This research uses quantitative methods using statistical tests. In this study, data were collected through an interpretive survey approach. Research data sourced from primary and secondary data. Primary data obtained through a set of questionnaires as a measurement tool, while secondary data obtained from documents or reports related to small and medium business actors in the city of Makassar. The population of this research is 136 entrepreneurs who lend to banks (bumn) in the city of Makassar (data source: several banks in the city of Makassar, 2019). The sampling of this study used the census sampling method (saturated sample).

This study promotes three variables, namely entrepreneurial character as an exogenous variable, then external funding as an intervening variable and the development of small and medium business actors as an endogenous variable. The measurement uses a five-point Likert scale of 1 (strongly disagree), 2 (disagree), 3 (disagree), 4 (agree), and 5 (strongly agree). Then a reliability test is performed using confirmatory factor analysis (CFA) to assess the construct validity of the proposed measurement theory. The analytical method uses structural equation modelling (sem) to test identifying research objectives.

The operationalization of variables, including entrepreneurial character is a character, character, and mental nature that always tries to utilize, manage and create opportunities that can provide financial and non-financial benefits. External funding is funding obtained by small and medium business actors originating from banks used for investment capital, working capital, and operational capital. The development of small and medium business actors is a success that is sourced from internal factors (sourced from within the entrepreneur) and external (sourced from outside) to achieve business goals through increased profitability and other achievements.

Figure 1

Conceptual framework

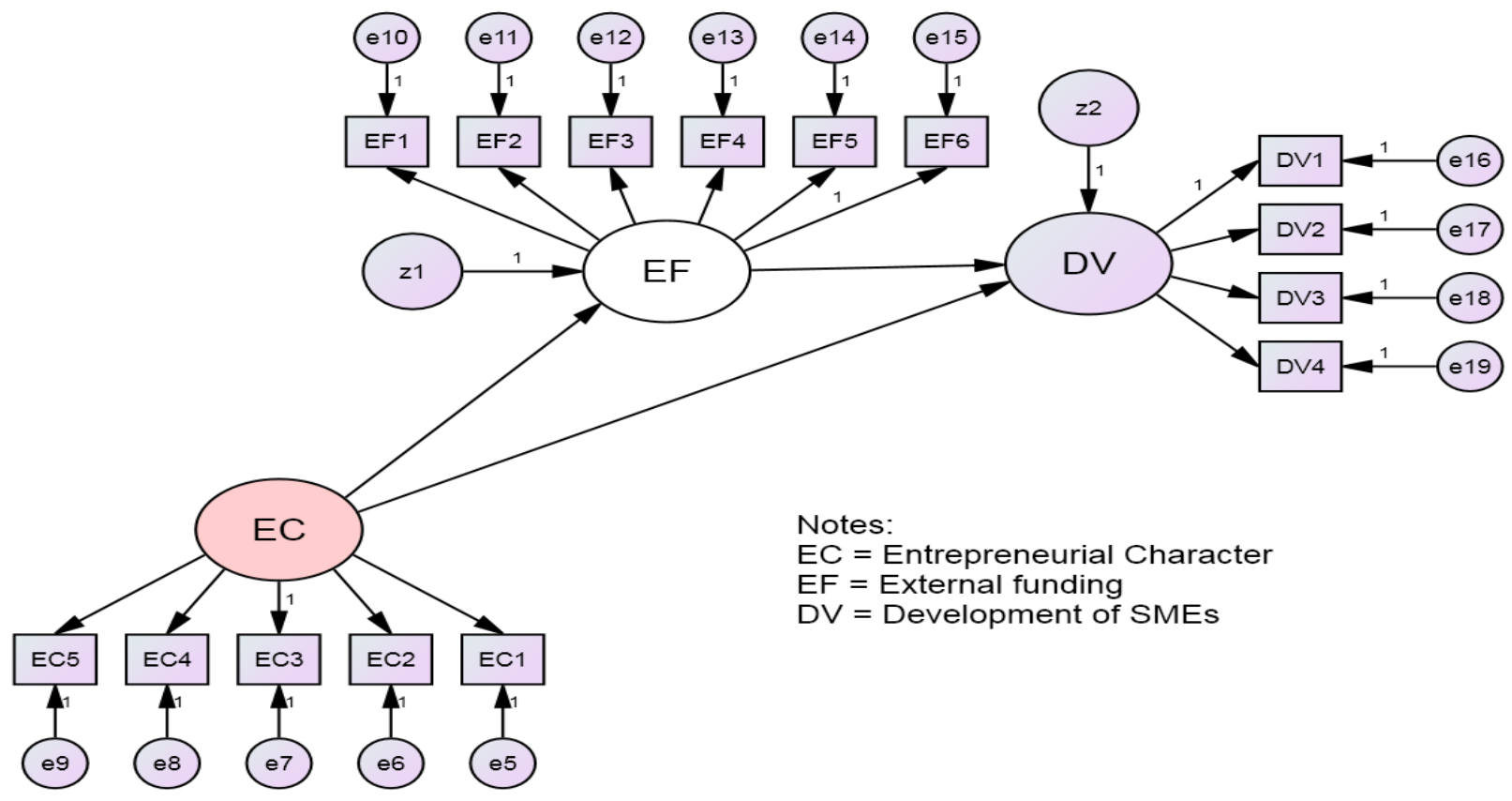

Based on Figure 1 shows the relationship between exogenous variables and endogenous variables, so the research hypothesis is described as follows.

$\mathrm{H}-1$ : there is a significant influence between the character of entrepreneurship on external funding. 
$\mathrm{H}-2$ : there is a significant influence between the nature of entrepreneurship on the development of small and medium business actor.

$\mathrm{H}-3$ : there is a considerable influence between external funding on the development of small and medium business actors

\section{Result}

The target sample was 136 people, but only 112 respondents returned the questionnaire completely. The respondents of this study are small and medium entrepreneurs registered in the Cooperative Service and Makassar small and medium business operators. Characteristics of respondents consisted of gender, age of the entrepreneur, length of entrepreneurship, and last education. The dominance of male entrepreneurs in entrepreneurship compared to female entrepreneurs, so that male entrepreneurs are more willing to take risks and have a higher entrepreneurial character.

The small business category participated more in this study because, in fact, the number of these categories was more than the medium business. Respondents aged 40 to 49 years showed a spirit of leadership and a high sense of entrepreneurship. The old group of entrepreneurship $<5$ years more participated in this study with a percentage of 79.5 per cent, which shows that they have had a quite good experience in entrepreneurship. The education level of entrepreneurs shows the level of ability in obtaining sources of capital. With a variety of complex requirements from financial institutions, so it requires extra time and energy in order to get a loan for venture capital.

Furthermore, the combination of sem and CFA is used to evaluate manifest variables in relation to each of the latent variables. In addition, path analysis is carried out to measure the significance of the proposed hypothesis. Based on the CFA test (table 2), the manifestation variable significantly influences the latent variable proposed.

Table 2

Measurement of manifest variables and latent variables

\begin{tabular}{|c|c|c|}
\hline Latent variable & Manifest variable & SIf \\
\hline \multirow[t]{5}{*}{ Entrepreneurial character } & Confidence & 0.748 \\
\hline & Task and outcome orientation & 0.734 \\
\hline & Take risks & 0.784 \\
\hline & Future orientation & 0.799 \\
\hline & Hard work & 0.797 \\
\hline \multirow[t]{6}{*}{ External funding } & Ease of getting credit or financing from individual institutions & 0.589 \\
\hline & The frequency of accessing credit or funding helps business growth & 0.553 \\
\hline & $\begin{array}{l}\text { Availability of information regarding credit or funding of small and medium } \\
\text { business actors }\end{array}$ & 0.559 \\
\hline & $\begin{array}{l}\text { The flexibility of small and medium business operators accessing credit or } \\
\text { funding }\end{array}$ & 0.727 \\
\hline & $\begin{array}{l}\text { Appropriateness of credit fulfilment from credit provider institutions with } \\
\text { the amount that small and medium business actors need }\end{array}$ & 0.605 \\
\hline & The increased amount of credit or funding & 0.549 \\
\hline \multirow{4}{*}{$\begin{array}{l}\text { The development of small } \\
\text { and medium businesses }\end{array}$} & Business profit & 0.678 \\
\hline & Level of sales & 0.706 \\
\hline & Customer growth & 0.880 \\
\hline & Total manpower & 0.812 \\
\hline
\end{tabular}

Note: ${ }^{* *}$ the correlation of manifest variable is significant at 0,05 level

Table 2 shows all dimensions of the entrepreneurial character of the latent variables that are significantly related and can represent the concept of entrepreneurial character in the research model. Reliability tests on all of these 
indicators produce loading factors $(>0.50)$ and t-values $(>1.960)$. Furthermore, all dimensions have been tested in the validity test of the external funding variables and the development of small and medium business actors, because they meet the loading factor $(>0.50)$ and t-value $(>1.96)$ requirements. Furthermore, the results of the structural equation model analysis on the variables of entrepreneurial character, external funding, and the development of small and medium business actors are presented as follows.

Figure 2

Results of structural equation model analysis

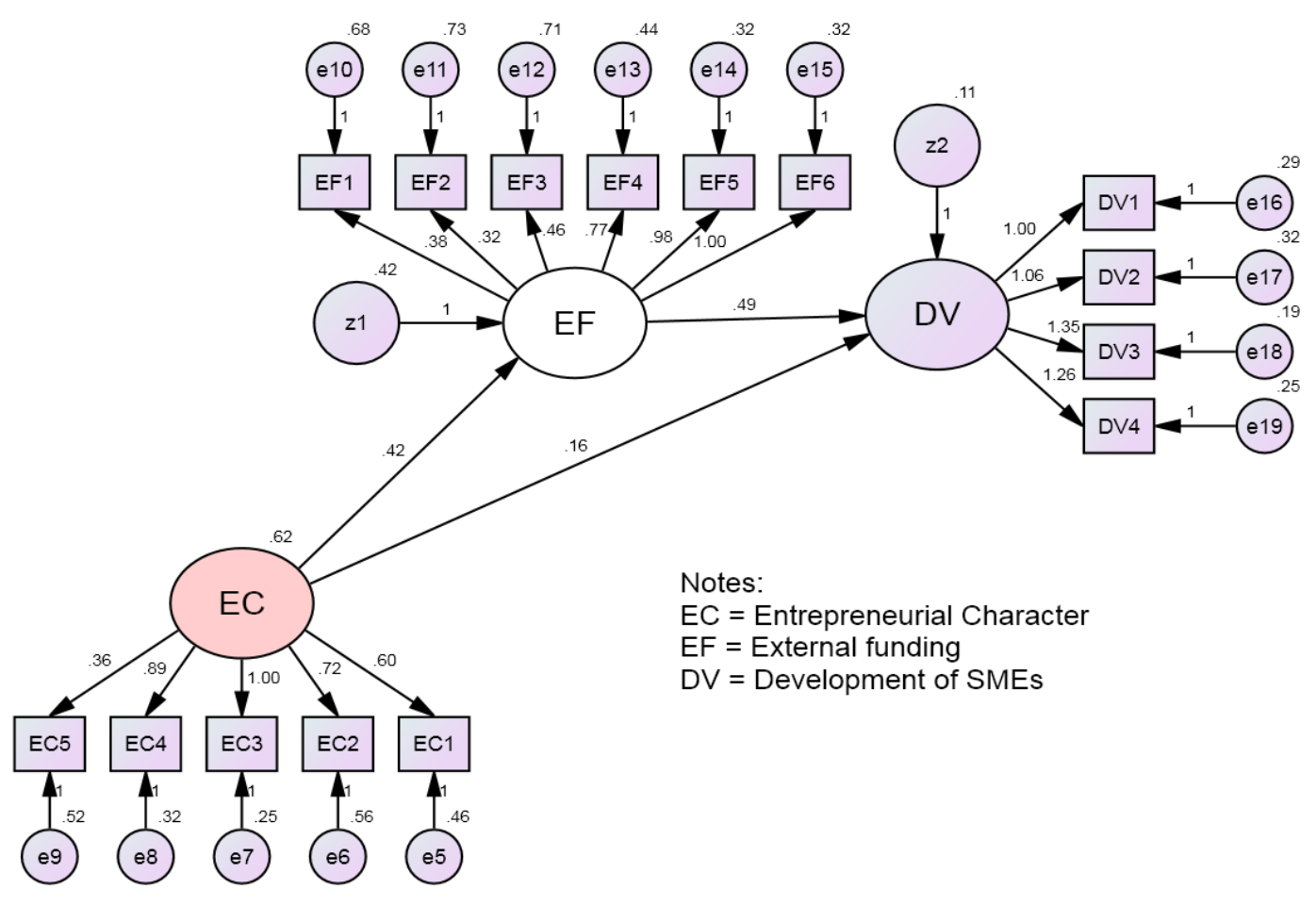

Tabel 3

Correlation between the independent and dependent variable

\begin{tabular}{ccccccc}
\hline Variables & Variables & Estimate & S.e & C.r & $\begin{array}{c}\text { P- } \\
\text { value }\end{array}$ \\
\hline $\begin{array}{c}\text { Entrepreneurial } \\
\text { character }\end{array}$ & $\rightarrow$ & External funding & 0.423 & 0.102 & 4.133 & $0.000^{*}$ \\
$\begin{array}{c}\text { Entrepreneurial } \\
\text { character }\end{array}$ & $\rightarrow \quad \begin{array}{c}\text { The development } \\
\text { of small and } \\
\text { medium } \\
\text { businesses } \\
\text { External funding }\end{array}$ & 0.491 & 0.090 & 5.447 & $0.000^{*}$ \\
\hline $\begin{array}{c}\text { The development } \\
\text { of small and } \\
\text { medium } \\
\text { businesses }\end{array}$ & 0.162 & 0.066 & 2.451 & $0.014^{*}$ \\
\hline
\end{tabular}

The results in table 3 show that the entrepreneurial character is proven to influence external funding (0.423), indicating that $\mathrm{h} 1$ is accepted. The entrepreneurial attitude is determined to influence the development of small 
and medium business actors (0.491), indicating that $\mathrm{h} 2$ is accepted. External funding has been shown to influence the development of small and medium business actors (0.162), indicating that $h 3$ is accepted.

\section{Discussion}

The findings of this study explain the attitude of courage to take the risk of being owned by entrepreneurs because of the demands to be brave and ready if the efforts carried out do not have the results that match expectations. Courage is accepting risks is accompanied by a full attitude of planning, having a vision, mission, working hard and having courage in a responsible manner. Furthermore, the results of this study elaborate on several key factors for entrepreneurial success: (1) the level of confidence is significant in entrepreneurship; (2) positive thinking about everything in business matters; (3) happy in pursuing the world of entrepreneurship; (4) by providing the best service, sales turnover can increase.

The influence of entrepreneurial character variables on external funding shows that there is a positive and significant influence. If the entrepreneurship character is improved in both quality and quantity, it will increase access to external funding sources. Entrepreneurial character plays a vital role in accessing external funding sources. The dominant dimension forming the entrepreneurial character variable is the risk-taking dimension; this shows that the dimension provides the greatest contribution to access to external funding sources.

Based on the results of data analysis, all indicators of variables accessing external funding sources and the development of small and medium business actors are declared valid and reliable both in all statements and in factor analysis. The coefficient of influence of the variable access to external funding sources on the development of small and medium business actors shows that there is a positive and significant influence. This result confirms that if access to external funding sources is improved in both quality and quantity, it will improve the development of small and medium business actors.

The variable access to external funding sources is measured through several dimensions: (1) the dimension of credit management with two indicators: ease of obtaining credit or funding from certain institutions; and the frequency of accessing credit or financing helps business growth. (2) The dimension of debt literacy with two indicators: availability of information on credit or funding of small and medium business actors; and the flexibility for small and medium enterprises to access credit or finance. (3) The dimension of the availability of collateral with two indicators, namely: the suitability of credit fulfilment from credit provider institutions with the amount that small and medium business actors need; and an increase in the amount of credit or funding.

Entrepreneurial characters such as liking a type of business that is challenging to achieve success, have good selfconfidence, and have exemplary nature and are more prominent in generating ideas or ideas that benefit his business. Furthermore, the results of this study elaborate on several key factors for the success of entrepreneurs: (1) planning a target of increasing business income; (2) benefits obtained from business development in terms of financial and non-financial; (3) work hard to prevent business risk; (4) calculates carefully the threats that will occur; and (5) using rational ways to recognize potential risks that will happen.

\section{Conclusions}

The role of the entrepreneurial character in accessing external funding sources plays a vital role in testing the development model of small and medium enterprises. The findings of this study explain that the dominant dimension forming the entrepreneurial character variable is the risk-taking dimension; this shows that the size provides an enormous contribution to access to external funding sources. The role of access to external funding sources in the development of small and medium business actors plays an essential role in testing the development model of small and medium business actors. The findings of this study explain that external funding 
sources as working capital and investment credit are essential for small and medium entrepreneurs. The influence of entrepreneurial character on access to external funding sources can be improved by increasing the level of self-confidence, thinking positively about everything in business matters, improving attitudes in the world of entrepreneurship, providing the best service.

\section{Bibliographic references}

Abduh, t. (2016). Pengaruh faktor internal dan eksternal terhadap kinerja ekspor usaha mikro kecil dan menengah melalui strategi ekspor di kota makassar. Disertasi. Universitas negeri makassar.

Akeem o. Ajani., \& o. Adekanmbi. (2016). Relationship between entrepreneurial characteristics and performance of small and medium scale enterprise (a study of smes in yaba Icda). International journal of business and social science, vol. 7(9), pp: 137-146.

Alyas., \& m. Rakib. (2017). Strategi pengembangan usaha mikro, kecil dan menengah dalam penguatan ekonomi kerakyatan (studi kasus pada usaha roti maros di kabupaten maros). Sosiohumaniora, vol 19(2), juli (2017), p.114- 120 .

Bakhshani, s. (2017). The relationship between non-financial factors, capital structure and the performance of the listed companies on the stock exchange. International journal of economics and financial issues, vol. $7(3)$.

Bannier, c.e., \& s. Zahn. (2014). Smes' growth heterogeneity - evidence from regional developments. International journal of business administration, vol. 5(2). Issn 1923-4007.

Boso, n., pejvak oghazi., john w. Cadogan., \& vicky m. Story. (2016). Entrepreneurial and market-oriented activities, financial capital, environment turbulence, and export performancein an emerging economy. Journal of small business strategy, vol. 26(1), pp: 1-24.

Fatimah., \& darna. (2011). Peranan koperasi dalam mendukung permodalan usaha kecil dan mikro (pelaku usaha kecil dan menengah). Jurnal ekonomi dan bisnis, vol 10(2),: 127-138.

Fitriani, r., \& t. Hermiati. (2010). Entrepreneurial skills and characteristics analysis on the graduates of the department of administrative sciences, fisip universitas indonesia. Journal of administrative sciences \& organization, vol. 17(3), pp: 262-275.

Fouad, m.a..a. (2013). Factors affecting the performance of small and medium enterprises (smes) in the manufacturing sector of cairo, egypt. International journal of business and management studies, vol. 5(2).

Frid, c.j., d.m. wyman., w.b. gartner., \& d.h. hechavarria. (2016). Low-wealth entrepreneurs and access to external financing. International journal of entrepreneurial behavior \& research, vol. 22(4), pp.531-555.

Herdianti, s., r. Pambudy., \& b. Burhanuddin. (2016). Entrepreneurial behavior influence on performance of women entrepreneurial sme agroindustry fisheries in padang city. International journal of science and research (ijsr), 5(10):1319-1325.

Isaksson, a., \& a.m.m. shahiduzzaman quoreshi. (2015). The impact of social factors on external financing of newly founded businesses. Citr electronic working paper series. Paper no. 2015/1.

Kerr, sari pekkala., w.r. kerr., \& tina xu. (2017). Personality traits of entrepreneurs: a review of recent literature. Working paper 18-047. 
Moorthy, m. Krishna., annie tan., caroline choo., chang sue wei., jonathan tan yong ping, \& tan kah leong. (2012). A study on factors affecting the performance of smes in malaysia. International journal of academic research in business and social sciences, vol. 2(4).

Nadhar, m. (2017). Pengaruh orientasi kewirausahaan dan motivasi kinerja terhadap kinerja usaha melalui komitmen berwirausaha pada usaha warung kopi di kota makassar. Disertasi. Universitas negeri makassar.

RetnRiawan., \& w. Kusnawan. (2018). Pengaruh modal sendiri dan kredit usaha rakyat (kur) terhadap pendapatan usaha (studi pada umkm di desa platihan kidul kec. Siman). Jurnal akuntansi dan pajak, 19(01), pp: 31-37.

Ruchkina, g., marina melnichuk., svetlana frumina., \& grzegorz mentel. (2017). Small and medium enterprises in the context of regional development and innovations. Journal of international studies, 10(4), 259-271. Doi:10.14254/2071-8330.2017/10-4/20.

Sayal, a., \& s. Banerjee. (2017). Factors influencing performance of smes: literature review and research propositions for smes. The marketing review, 17(1).

Schmitt, u. (2018). Supporting the sustainable growth of smes with content- and collaboration-based personal knowledge management systems. Journal of entrepreneurship and innovation in emerging economies, vol. 4 , issue 1.

Sharafeddine, r.i. (2016). Financial capital an entrepreneurial factor of production. American journal of economics, 6(4), pp: 226-239

Sitharam, s., \& m. Hoque. (2016). Factors affecting the performance of small and medium enterprises in kwazulunatal, south africa. Problems and perspectives in management, 14(2-2), 277-288.

Sukoco, abu rizal f., mg.wi. Endang n.p., zahroh za. (2015). Pengelolaan modal kerja usaha mikro untuk memperoleh profitabilitas (studi pada ud. Warna jaya periode 2011-2013). Jurnal administrasi bisnis (jab), vol. 22(1).

Wahyuniardi, r. (2012). Evaluasi penyaluran kredit usaha rakyat. Infomatek, vol. 14(1).

Wakkee, i., m. Van der veen., \& w. Eurlings. (2015). Active growth paths for smes. The journal of entrepreneurship, vol. 24(2).

Wiradirnata, r. (2016). Pengaruh faktor internal dan eksternal terhadap minat dan motivasi dalam pengambilan keputusan berwirausaha (studi pada pensiunan pegawai negeri sipil nasabah pt bank tabungan pensiunan nasional tbk cabang makassar. Disertasi. Universitas negeri makassar.

Yunus, m. (2017). Determinan faktor yang mempengaruhi kompetensi kewirausahaan dan pengaruhnya terhadap kinerja usaha kecil menengah (pelaku usaha kecil dan menengah) di kota makassar (penjual tekstil dan garmen). Disertasi. Universitas negeri Makassar.

Esta obra está bajo una Licencia Creative Commons

Attribución-NoCommercial 4.0 International

(cc) EYY-NC 